\title{
A Study on Creativity of Secondary School Students in Lakhimpur and Dhemaji Districts of Assam
}

\author{
Dr. Lakshinandan Nath \\ Principal, Laluk College, Department of Education, District-Lakhimpur, Assam
}

\begin{abstract}
The present study investigated the creativity of secondary school students in Lakhimpur and Dhemaji districts of Assam.The study was conducted on two hundred class-X students by giving due representation to boys (100) and girls (100) as well as rural and urban localities of bothdistricts. The 08 Government and Private secondary schools were selected using stratified random sampling technique, and students were selected using simple random sampling technique.The descriptive survey method is used for data collection using creativity test developed by Baqer Mehdi. TheThere was no significant mean difference between male and female secondary students of both the districts; but there are significant difference between rural/urban and government/private in creativity of secondary students of both the districts.
\end{abstract}

Keywords: Creativityand Secondary School Student

\section{Introduction}

Creativity has been seen as the only uniquely "human" characteristic, defining an area where, for instance, microelectronics cannot go. In this view, creative thinking is a base of human dignity in an age where machines, especially computers, seem to be taking over routine skilled activities and everyday thinking. Openness, courage, and the like, which are themselves seen as both pre-requisites for and results of a healthy personality, creativity is thought to foster positive adjustment to life. In educational settings, creativity is seen as a special approach to learning that involves both "creative" teaching and "creative" learning strategies. These strategies facilitate learning and are simultaneously a result of appropriate teaching and learning.

\section{Review of Related Study}

Alam (2009) conducted a study on academic achievement in relation with creativity and achievement motivation. The study aims to find out the extent of relationship between creativity and achievement motivation of the students and academic achievement. The findings revealed a significant positive correlation between (i) creativity and academic achievement (ii) achievement motivation and achievement.

Barbara, Imperatori (2011) studied malevolent creativity: does personality influence malicious divergent thinking? These results confirm the link between personality and malevolent creativity, corroborating the general model of aggression and extending understanding of malevolent creativity, a new subfield of creativity research

Baran, Erdogan, \&Cakmak (2011) investigated the relationship between creativity and mathematical ability of 6 year old students. In this study, data for creative ability were collected using a general creativity instrument (Torrance Tests of Creative Thinking) whereas data for mathematical ability were gathered using a mathematical test, measuring aspects of informal (e.g. fewer/more, counting) and formal Mathematics (e.g. numbers, calculations). Results revealed that there was no statistically significant relationship between mathematical ability and creativity or even between mathematical ability and creativity indicators (such as fluency, originality and elaboration).

\section{Need of the Study}

Creativity refers to having inventive, productive and imaginative qualities. A creative person is able to link the existing information with new information in productive ways. Students who are creative may often be referred to as gifted or talented. Creative students, for example have a keenly observe a situation and have a desire to improve their abilities, produce variety of possible solutions to problem, are curious, original, comfortable with ambiguity, able to work independently, able to analyse and synthesise information, demonstrate compulsivity and an urgency to complete a task or execute an idea and have multiple latent abilities and characteristics of persistence. Thus, creative one plays with the existing knowledge and information and combines in a unique ways that a creative product or idea is formed.This motivates the investigator to conduct a study on creativity of secondary school students of Lakhimpurand Dhemaji districts of Assam.

\section{Statement of the Problem}

The problem of the present study has been stated as follows:

"A Study on Creativity of Secondary School Students in Lakhimpur and Dhemaji Districts of Assam"

\section{Objectives of the Study}

The study is designed with the following objectives:

1) To test the significance of the mean differences on Creativity of (a) male and female (b) rural and urban (c) government and private secondary school students of Lakhimpur and Dhemaji Districts (total sample) of Assam.

2) To test the significance of the mean differences on Creativity of (a) male and female (b) rural and urban (c) government and private secondary school students of Lakhimpur District of Assam. 


\section{International Journal of Science and Research (IJSR) \\ ISSN (Online): 2319-7064 \\ Index Copernicus Value (2015): 78.96 | Impact Factor (2015): 6.391}

3) To test the significance of the mean differences on Creativity of (a) male and female (b) rural and urban (c) government and private secondary school students of Dhemaji District of Assam.

\section{Hypotheses of the Study}

The hypotheses are stated as under:

1) There is no significant difference in the mean scores of creativity between (a) male and female (b) urban and rural (c) government and private secondary school students of Lakhimpur and Dhemaji Districts (total sample) of Assam.

2) There is no significant difference in the mean scores of creativity between (a) male and female (b) urban and rural (c) government and private secondary school students of Lakhimpur District of Assam.

3) There is no significant difference in the mean scores of creativity between (a) male and female (b) urban and rural (c) government and private secondary school students of Dhemaji District of Assam.

\section{Methodology of the Study}

The Descriptive approach is used in the study.

\section{Population of the Study}

The population of the present study constitutes all the secondary school students studying in class $\mathrm{X}$ who are the creativeof Lakhimpurand Dhemaji districts of Assam.

\section{Sample of the Study}

The sample is of small number of representative individuals from the population. This study is conducted on a sample of 200Students, 100 boys and 100 girls selected randomly from 08 Government and Private secondary schools of Lakhimpur and Dhemaji districts of Assam. The schools were selected using stratified random sampling techniqueand students were selected using simple random sampling technique..

\section{Tool Used}

The researcher used the verbal creativity test developed by Baqer Mehdi. This test has four activities. First three activities have three questions or problems, each problem related to three factors namely; fluency, flexibility and originality and last activity are descriptive type. Only 1 hour were given to administer it to the students.

\section{Statistical Techniques Used}

In this study various statistical measures such as Mean, SD and t-test are used.

\section{Result and Discussion}

Collected data through above mentioned inventories were analyzed in terms of mean, standard deviation and t-test method. The results have been presented in the tables.

Hypothesis-1: There is no significant difference in the mean scores of creativity between (a) male and female (b) urban and rural (c) government and private secondary school students of Lakhimpur and Dhemaji Districts (total sample) of Assam.
Table 1: Showing the mean, standard deviation and t-value of the creativity between (a) male and female, (b) urban and rural and (c) government and private secondary school students in Lakhimpur and Dhemaji Districts (total sample) of Assam

\begin{tabular}{|c|c|c|c|c|c|c|}
\hline Variable & Group & $\mathrm{N}$ & Mean & $\begin{array}{l}\text { Standar } \\
\text { deviatic }\end{array}$ & $\begin{array}{c}\mathrm{t}- \\
\text { value }\end{array}$ & Remark \\
\hline \multirow{6}{*}{ Creativity } & Male & 100 & 51.81 & 11.33 & \multirow[t]{2}{*}{0.35} & Not \\
\hline & Female & 100 & 51.29 & 9.44 & & Significanc \\
\hline & Rural & 100 & 48.99 & 9.58 & \multirow[t]{2}{*}{1.73} & Not \\
\hline & Urban & 100 & 51.53 & 11.07 & & Significanc \\
\hline & Government & 100 & 51.03 & 11.42 & \multirow[t]{2}{*}{0.47} & Not \\
\hline & Private & 100 & 50.34 & 9.07 & & Sig \\
\hline
\end{tabular}

The results from above Table-1 showed that the mean scores on creativity of male and female students were 51.81 and 51.29 respectively. When the t-test was applied to compare the mean scores of both the groups, it was found that the calculated t-value 0.35 was less than the table value 1.97 at 0.05 levels of significance. Therefore, the null hypothesis is accepted. This means there was no significant difference on creativity between male and female secondary students of both the districts (total sample).

The mean scores on creativity of both rural and urban students were 48.99 and 51.53 respectively. When the t-test was applied to compare the mean scores of both the groups, it was found that the calculated t-value (1.73) was lower than the table value 1.97 at 0.05 level of significance. This means that the mean difference was donotsignificant. Hence, hypothesis is accepted. This further means that rural and urban secondary school students of both the districts (total sample) were having similar on creativity.

The mean scores on creativity of both government and private students were 51.03 and 50.34 respectively. The computed CR $(\mathrm{t})$ between their mean differences was 0.47 . This was found not significant at 0.05 level. Hence, hypothesis is accepted. This means that there was $n$ significant difference between creativity of government and private secondary students of both districts (total sample).

Hypothesis-2: There is no significant difference in the mean scores of creativity between (a) male and female (b) urban and rural (c) government and private secondary school students of Lakhimpur district.

Table 2: Showing the mean, standard deviation and t-value of the creativity between (a) male and female (b) urban and rural (c) government and private secondary school students in Lakhimpurof Assam

\begin{tabular}{|l|c|c|c|c|c|c|}
\hline Variable & Group & $\mathrm{N}$ & Mean & $\begin{array}{c}\text { Standard } \\
\text { deviation }\end{array}$ & $\begin{array}{c}\mathrm{t}- \\
\text { value }\end{array}$ & Remark \\
\hline \multirow{5}{*}{ Creativity } & Male & 50 & 53.8 & 11.32 & 0.39 & $\begin{array}{c}\text { Not } \\
\text { Significance }\end{array}$ \\
\cline { 2 - 6 } & Female & 50 & 52.94 & 10.58 & & Significance \\
\cline { 2 - 6 } & Rural & 50 & 48.18 & 9.35 & 2.70 & Significan \\
\cline { 2 - 6 } & Urban & 50 & 53.8 & 11.32 & & \\
\cline { 2 - 5 } & Government & 50 & 53.08 & 11.44 & 1.23 & $\begin{array}{c}\text { Not } \\
\text { Significance }\end{array}$ \\
\cline { 2 - 5 } & Private & 50 & 50.6 & 8.49 & & \\
\hline
\end{tabular}

From the above Table, it can be observed that the mean scores of both male and female students were 53.8and 52.94respectively. When the t-test was applied to compare the mean scores of both the groups, it was found that the 


\section{International Journal of Science and Research (IJSR) \\ ISSN (Online): 2319-7064}

Index Copernicus Value (2015): 78.96 | Impact Factor (2015): 6.391

calculated t-value (0.39) is less than the table value 1.98 at 0.05 level of significance. Hence, hypothesis is accepted. This means that there was no significant difference in creativity of male and female secondary students of Lakhimpurdistrict.

The mean scores on creativity of both rural and urban students were 48.18 and 53.8 respectively. When the t-test was applied to test the significance of the mean difference between these groups, it reported a CR $(\mathrm{t})$ value 2.70. This was found to be significant. Hence hypothesis is rejected. This further means that there was great difference on creativity of both rural and urban secondary students of Lakhimpurdistrict.

The mean scores on creativity of both government and private students were 53.08 and 50.6 respectively. The computed $\mathrm{t}$-value between their mean differences was 1.23 which were found to be not significant at 0.05 levels. Hence hypothesis is accepted. Therefore government and private secondary students of Lakhimpurdistrict were found similar on creativity.

Hypothesis-3: There is no significant difference in the mean scores of creativity between (a) male and female (b) urban and rural (c) government and private secondary school students of Dhemaji District.

Table 3: Showing the mean, standard deviation and t-value of the creativity between (a) male and female (b) urban and rural (c) government and private secondary school students in DhemajiDistrict of Arunachal Pradesh

\begin{tabular}{|c|c|c|c|c|c|c|}
\hline Variable & Group & $\mathrm{N}$ & Mean & $\begin{array}{l}\text { Standard } \\
\text { deviation }\end{array}$ & $\begin{array}{c}\mathrm{t}- \\
\text { value }\end{array}$ & Remark \\
\hline \multirow{6}{*}{ Creativity } & Male & 50 & 49.82 & 11.11 & \multirow[t]{2}{*}{0.09} & \multirow{2}{*}{$\begin{array}{c}\text { Not } \\
\text { Significance }\end{array}$} \\
\hline & Female & 50 & 49.64 & 7.92 & & \\
\hline & Rural & 50 & 49.8 & 9.84 & \multirow[t]{2}{*}{1.18} & \multirow{2}{*}{$\begin{array}{c}\text { Not } \\
\text { ignificance }\end{array}$} \\
\hline & Urban & 50 & 52.26 & 10.88 & & \\
\hline & Government & 50 & 48.98 & 11.14 & \multirow[t]{2}{*}{0.53} & \multirow{2}{*}{$\begin{array}{c}\text { Not } \\
\text { Significance }\end{array}$} \\
\hline & Private & 50 & 50.08 & 9.70 & & \\
\hline
\end{tabular}

The mean scores on creativity of male and female students were 49.82 and 49.64respectively. The computed CR (t) between their mean differences is 0.09 . This was not found significant at 0.05 level. Hence, hypothesis is accepted. This further means that there is no difference on creativity of male and female secondary students of DhemajiDistrict.

The mean scores on creativity of both rural and urban students were 49.8 and 52.26respectively. The computed tvalue between their mean differences was 1.18. This was found not significant at 0.05 level. Hence hypothesis is accepted. Therefore, rural and urban secondary students of Dhemajiwere found similar on creativity.

The mean scores on creativity of both government and private students were 48.98and 50.08respectively. When the t-test was applied to compare the mean difference of both the groups, it was found that the calculated t-value $(0.53)$ was less than the table value 1.98 at 0.05 levels of significance. This means that government and private secondary students of DhemajiDistrict have no differences in their creativity

\section{Findings of the Study}

1) There was no significant mean differenceon creativity between male/female, rural/urban as well as government/private secondary students of both the districts of Assam.

2) There was no significant mean difference on creativity between male/female as well as government/private secondary students of Lakhimpur district; but there are significant difference between rural and urban secondary students of Lakhimpur.

3) There was no significant mean difference on creativity between male/female, rural/urban as well as government/private secondary school students of Dhemaji District.

\section{References}

[1] Agarwal, S. (1982). A Study of Creativity as a Function of Self-Esteem, Risk-Taking and Home Background. Doctoral Dissertation in Education, Agra Univ. Cited in M.B.Buch IIIrd Survey.

[2] AlamMd.M (2009). Effect of Creativity and SocioEconomic Status of Students on Academic Achievement, Indian Psychological Review, Vol. 72, No. 1,Agra, Agra Psychological Research Cell. Bisht, A.R. (1979). Academic Achievement and Academic Stress ISPT. Journal of Research, 3(2), 16-2.

[3] Buch, M.B (Ed) (1979). Second Survey of Research in Education, Baroda, Centre of Advanced Study in Education, M.S. University.

[4] Buch, M.B. (Ed.) (1987).Third Survey of Research in Education, Baroda, Centre of Advanced Study in Education, M.S. University.

[5] Buch, M.B (Ed.) (2007). Sixth all India Educational Survey, Vol. I \& II, New Delhi NCERT.

[6] Garrett, H.E., (1968). General Psychology, New Delhi, Eurasia Publication House, (IND. Reprint).Gaur, Vijender (2012) A Study of Classroom Morale of Senior Secondary School Students in Relation to Their Locus of Control, Socio- Economic Status and Intelligence, An Published Thesis, Department of Education, Maharshi Dayanand University, Rohtak-124001.

[7] Koul, L. (1997). Methodology of Educational Research, New Delhi: Vikash Publishing house Pvt. Ltd.

[8] Morgan (1924), Psychology of Perspectives Jan. Vol. $1076(1)$ 